Journal of Social Sciences (COES\&RJ-JSS)

ISSN (E): 2305-9249 ISSN (P): 2305-9494

Publisher: Centre of Excellence for Scientific \& Research Journalism, COES\&RJ LLC

Online Publication Date: $1^{\text {st }}$ April 2019

Online Issue: Volume 8, Number 2, April 2019

https://doi.org/10.25255/jss.2019.8.2.306.326

\title{
Reviewing the mediating role of work/life balance and motivational drivers of employee engagement on the relationship between talent management and organization performance
}

\author{
Bader Obeidat \\ Department of Business Management, School of Business, The University of Jordan, \\ Amman, Jordan, b.obeidat@ju.edu.jo \\ Areej Al-Khateeb \\ MBA at School of Business, The University of Jordan, Amman, Jordan \\ Abdallah Abu Abdallah \\ MBA/Accounting Graduate at School of Management and Finance, The University of \\ Jordan-Aqaba Branch, Jordan, abdallah.fareed@yahoo.com

\section{Ra'ed Masa'deh} \\ Department of Management Information Systems, School of Business, The University of \\ Jordan, Amman, Jordan, r.masadeh@ju.edu.jo
}

\begin{abstract}
:
The purpose of this paper is to reviewing the literature and the associations among talent management, work life balance, motivational drivers of employee engagement and organization performance. Both work life balance and motivational drivers of employee engagement were reviewed as mediators between talent management and organization performance.
\end{abstract}

\section{Keywords :}

Talent management, Work/life balance, Motivational drivers of employee engagement.

\section{Citation:}

Obeidat, Bader ; Al-Khateeb, Areej; Abu Abdallah, Abdallah ; and Masa'deh, Ra'ed (2019); Reviewing the mediating role of work/life balance and motivational drivers of employee engagement on the relationship between talent management and organization performance; Journal of Social Sciences (COES\&RJ-JSS), Vol.8, No.2, pp:306-326; https://doi.org/10.25255/jss.2019.8.2.306.326. 


\section{Introduction}

Labor market is no further characterized by stability and long-term security; it becomes atypical and dynamic market for organization to face, consists of many new and challenging traits such as outsourcing, contingencies, mobility (Nilsson and Ellström, 2012) shorter product life cycle and unique products (Samantara and Sharma, 2014). This dynamic market is characterized of being a knowledge based economy, which was emerged due to many new factors such as globalization, strong competition, technological advancement (Mathew, 2015) and labor demographic changes which made human resources a significant asset in achieving organizational success and prosperity (Jauhari, et al., 2013), strong competitive advantage that is hard to be imitated (Coff and Kryscynski, 2011) and created "war of talent at the global level". Therefore, organizations are continually looking for knowledgeable and talented workers who optimize their performance and efficiency (Slavković, et al., 2015). Those talents are organizations' tool to face unpredictable and competitive environment. Talent management is about attracting, developing and retaining talented employees (Jauhari et al, 2013) to outperform competitors and succeed (Tansley, 2011). Talent management is a comprehensive approach that needs to be carefully assessed and planed; its importance emerges due to the global shortage of talent (Hejase, et al., 2016). Talent management is about having the right person in the right place to do the right job and prevent organizations' attrition. Employee engagement and work / life balance provide managerial instruments that emphasize the harmony between employees and organizations (Vinnie, et al., 2013), appreciating employees as human beings and enhancing employees' motivation and efficiency (Mahanta, 2015), help organizations to manage talent efficiently and improve performance. Engaged employees have positive consequences on organizations' performance. They are more productive, creative, loyal and working ahead to achieve organization goals (Jauhari, et al., 2013). Moreover, work life balance achieves organization stability through preventing the loss of talented employees (Mazur-Wierzbicka, 2015). Organizations are seeking positive outcomes from its talent management approach and this systematic approach has to be effective by creating a pool of gifted employees who are capable to achieve organization goals and objectives through being motivated and qualified.

Based on that, this research was conducted to review the literature between talent management and organization performance defined by human resources and motivation. It also examines the role of motivational drivers of employee engagement and work life balance practices to support and smooth this relationship between talent management and organization performance.

\section{Literature Review}

This section represents the literature review of the study. It introduces how other researchers explain and define the study's main variables; [talent management, work/life balance, drivers of employee engagement and organization performance]. This section starts with the primary variable of the study; talent management, it focuses on how the technological economy highlighted the importance of human assets (Nilsson and Ellström, 2012) and how talent employees can carry out organizations to be a successful and efficient (Kucherov and Zavyalova, 2012). The talent management concept has been 


\section{Reviewing the mediating role of work/life balance..}

defined by many researchers as talent acquisition, talent development and talent retention. Work life balance and motivational drivers of employee engagement give organizations the ability to implement talent management practices efficiently and effectively through their ability to enhance a working environment that is comfortable and easy to work within.

\section{Talent Management}

Talented employees are those employees with outstanding abilities, knowledge, leadership, skills, intelligence, potential, performance and brightness and they will achieve both; extraordinary individual achievements and remarkable organizations' performance (Latukha and Tsukanova, 2015). Talented employees are those ones who are critical players in performing and accomplishing organizations' strategies (Egerová, 2013). They are organizations' potential leaders (Nijs, et al., 2014). There are different viewpoints about talent origin; for some researchers it is an innate and a gift from Allah arises within a person from his birth and can be developed through learning, but still it can't be acquired through life without having it as an initial and natural characteristic of birth (Latukha and Tsukanova, 2015). Others argue that talent is a capability everyone has and can be developed through continuous learning (Tansley, 2011); it depends on the organization's ability to find out and uncover their employees' talent and then develop it (Ross, 2013).

Organizations consider talent as an important asset to develop and succeed, but talent is not easy to find. Different ways to utilize talents depending on organization definition of talent and how it matched with organizations' goals and objectives (Egerová, 2013). All over, defining talent in a precise way is still a difficult task. Nijs and associates (2014) define talent as "Talent refers to systematically developing innate abilities of individuals that are deployed in activities they like, find important, and in which they want to invest energy. It enables individuals to perform excellently in one or more domains of human functioning, performing better than other individuals of the same age or experience, or as performing consistently at their personal best" (Page, 182). Talent also defined as persons' abilities that drive him/her to be extraordinary and have great competencies; it leads him/her to have exceptional performance and achievements (Ross, 2013).

Talent management has become recently an important subject highly considered by managers and researchers (Nilsson and Ellström, 2012). It was introduced in the late 1990 by the War of Talent book that was written by McKinsey consultants. This book boomed out the importance of talent and qualified employees for organizations in facing a highly challenging environment (Mathew, 2015) and gaining long term competitive advantage (Latukha and Tsukanova, 2015) that is hard to be imitated (Coff and Kryscynski, 2011). Since 2011 experimental studies about talent management has been increased extensively but still talent management research is under criticisms because of many reasons; such as it concentrates on talent management effectiveness and efficiency from an organizations' point of view and skip the employees' point of view (Thunnissen, 2016).

In more details talent management initial vision was emerging between 1980s and 1990s and get more attention between 1990s and 2000s, it started by figuring out the real 
importance of linking employees' needs with business needs, which can be done through concentrating more on human touch to give organizations the ability to succeed and compete. Globalization and technology exposure organizations into different cultures, different management practices and different leadership styles leading to raise the importance of human touch (Cascio and Boudreau, 2016). The shortage of talents, labor force aging and the flexibility of human mobility made talent management important (Hejase, et al., 2016), this made organizations focus more on attracting, developing and retaining their current and future talented employees.

Talent management is about continuously developing an organization to reach its goals; this can be done through an advanced network of relationships that link all organizations' functions together and through continuous effort in employees' knowldge (Hejase, et al., 2016). According to Majeed (2013) talent management is the consistency between employees and employer objectives, it is about handling employees' issues and exploiting their capabilities from the moment they enter the organization till the moment they leave. Following on, talent management is a human resources department effort in tracking the stream of talent within their organization and chase talented employees' abilities and performance (Nilsson and Ellström, 2012). Talent management changes the traditional function of the human resources from staffing and recruiting to obtain a talent pool plan and follow up talented employees and focus on retaining excellent ones (Kim and McLeanw, 2012; Nilsson and Ellström, 2012).

As mentioned by Hejase and associates (2016) "At the United Nations Development Program, talent management is defined as "an organizational capacity to identify the right person for the right job and at the right time" (Page, 505). It is about supplying an organization with the human capital that matches its goals (Bandari and Migiro, 2015). Although there is no specific definition of talent management, but still there is a general assent that it's mainly about the importance of human capital to the success of any organization (Egerová, 2013) and how organizations can perform efficiently through its people. Moreover, the talent management broader definition as mentioned by many researchers (Mathew, 2015; Ulrich and Allen, 2014) is the process of attracting, developing and retaining qualified employees to satisfy organizations' needs. Those three main concepts of talent management have to be developed and managed holistically and in parallel way together to work in their best (Hejase, et al., 2016).

Many factors in organizations' internal and external environment are affecting talent management practices. One example of external factors could be workforce aging where the organizations are going through hard processes to fill retirement vacancies and choose from less experienced employees who are available in the labor market. From another point of view internal factors implement more critical role in shaping talent management practices where Human Resources policies influence the most (Thunnissen, 2016). Organizations' human resources policies and practices should be established carefully to utilize talented employees' skills and abilities. Talent pool must be developed in a way that highlights the critical functions and duties which will accomplish organizations' strategies (Kim and McLean, 2012). 


\section{Reviewing the mediating role of work/life balance..}

Toterhi and Recardo (2013) mentioned the concept of talent funnel where high level managers and human resources departments are tracking their best people through their learning curve, and they discussed the flaws that both human resources department and high level management might face while doing that. Their suggestions to overcome those flaws were through letting talent management strategy a complementary strategy for the whole organization; give more time to peoples' issues inside the organization. The human resources department and the upper management should work together side by side; the human resources department formulates the talent management strategy and the managers implement it. The more globally an organization grows, the more complicated its talent management becomes (Kim and McLean, 2012). According to (Ulrich and Allen, 2014; Mathew, 2015) talent management definition and for the purpose of this study talent management will be dimensioned through Talent Attraction, Talent Development and Talent Retaining.

\section{Talent Attraction}

The late Steve Jobs once said that hiring the best people was a massive factor in his own success. The threat of "brain drain" from one country to another and globalization both threatencountries and organizations all over the world of losing their talents (Harvey, 2014). Organizations have an intense concern in attracting knowledgeable employees because they have a very important consequence on organizations' success, but attracting the right people consumes both organizations' time and cost. The main challenges face organizations in finding talented employees are to find the ones with abilities that are convenient to the organizations' strategies, then match between those talent culture and organization own culture (Majeed, 2013). Another challenge appears when an organization tries to evaluate the accuracy of available information about talented employees and estimate their willingness to adapt and engage in organizations' social system (Coff and Kryscynski, 2011). Talented employees are more demanding than ordinary ones; they understand their value and their scarcity in the labor market (VidalSalazar, et al., 2016).

Moreover, organizations must take in consideration while attracting talented employees; their acceptance to change their current status (Slavković, et al., 2015), fray between competitors to attract them, their ability to move to another company or country (Majeed, 2013) and their shortage in the labor market. The human resources department plays a significant role in attracting talented employees who have developmental potentials, this can be done through stimulation an attractive environment where those new talents find opportunities and develop their own capabilities (Slavković, et al., 2015). It was easier before to attract key employees since money was a powerful tool to do this, but nowadays things have changed and non-monetary attraction factors arise next to financial ones and each person has different aspect that matter to him. A benefit system no longer can be designed in simple and consensus way, it cannot be accepted within all employees in an organization, even organizations need a benefit system that is flexible and can face its uncertain environment (Vidal-Salazar, et al., 2016). The human resources department can support their organization efforts in positioning their employer brand image through developing a unique human capital practice (Kucherov and Zavyalova, 2012) and implementing efficiently its main functions; staffing, training, developing, maintenance and motivation. 
According to Kucherov and Zavyalova (2012) and for the purpose of this study three dimensions are considered to study talent attraction; Human Resources policies and procedures, Organizations' current talent and star employees who will play a significant role in impress outside talent and finally, current employee interpersonal networks which will address new potential employees.

\section{Talent Development}

As mentioned earlier, one side of talent management is to externally attract the right people to fill the right jobs, but a more solid talent strategy is needed in the long run to overcome the talent shortage in the market and the accumulated cost of external hiring (Slavković, et al., 2015). Either externally or internally once talented employees are inside an organization, they must continuously be monitored and developed to prevent them from being absolute and harm organization performance (Bhattacharyya, 2015; Panda and Sahoo, 2015).

Talent development is a main part in the talent management strategy of any organization and the human resources strategy (Panda and Sahoo, 2015). Organizational approaches to develop talent can vary as follows; an exclusive approach which is more common to develop key players in organization, an inclusive approach that emphasize on all employees' capabilities or finally, a hybrid approach that combine both exclusive and inclusive and it is the preferred one (Garavan, et al., 2012). As defined by Slavković and associates (2015) talent development is about developing employees' career path to help organizations face uncertainty through building a hyper talent pool which is always ready to supply knowledge and skills and it is in parallel with organizations' goals and objectives. This talent pool is an essential tool for organizations to face its changeable and ambiguous environment (Bhattacharyya, 2015), but still there is no clear definition of talent development and there is a shortage in its literature reviews (Mehdiabadi and Li, 2016).

Through talent development organizations will concentrate to develop what really matters for its success (Garavan, et al., 2012). Organizations will equip its employees with the knowledge and abilities to satisfy its future needs and conserve its loyal and " $A$ " star employees (Panda and Sahoo, 2015). Panda and Sahoo (2015) assembled a comprehensive model to achieve talent development within an organization, starting with having a performance evaluation program that gives insights into what could be done properly in the future and in the benefit of organizations. After that, stimulates talent development through training. Moreover, organization has to develop a path of growth that work towards achieving both employees and organization goals in parallel. Finally, it must emphasize on effective communication between leaders and subordinate, and between subordinate themselves to motivate knowledge sharing and innovation within organizations. Managers are key players in the talent development process; they play a significant role in leading their employees to achieve extraordinary performance. They concentrate on "everyday psychology"; it is an approach for managers to follow the psychological side of their employees' mind to support their performance through being a role model and has effective communication with them (Axelrod, 2015). Accordingly to Slavković and associates (2015) and for the purpose of this study four items are 


\section{Reviewing the mediating role of work/life balance..}

representing talent development; High-performance talented employees have access to training aimed to develop their potential, Trainings activities are focused on developing specific competencies and skills that the organization need, the organization concentrates employees training on mentoring and coaching and finally, the organization has a group of talented employees.

\section{Talent Retention}

Importance of talent retention has been accelerated because of globalization and challenges of talent shortage that face multi-national organization in developing countries (Epie, 2014). As George (2015) illustrates organizations become in danger when they lose employees because of the accumulated cost of hire and train substitute, danger of loose organizations' experience and knowledge and negative consequences on organizations' performance. Other threats can occur when organizations' knowledge is in danger to be captured by competitors, time consuming, difficulty of finding new employees who fit with organizations' culture (Bhattacharyya, 2015) and threat of followers to leave (Bryant and Allen, 2013). So retaining talented employees is a must and a highly sensitive issue to look after. It is better to study the reasons behind talent retention rather than talent turnover since turnover doesn't always mean something bad, especially when low performance employees leave (George, 2015). It gives organizations the opportunity to focus on retaining key and valuable employees (Epie, 2014).

Talent retention is about having attached employees and minimizing their intentions to leave the organization. Some important ways to retain talent is through engaging employees (Glen, 2006). Spread a culture where leaders are not feeling in danger from their talented substitute, this will be important to not lose talented employees (Bhattacharyya, 2015). Many factors are influencing talent retention such as; employee satisfaction, growth opportunity, commitment, leadership style, financial rewards, working conditions flexibility, security and others. Each factor of the mentioned above differs in its influential degree and can be different according to different organizations' cultures inside and outside (Epie, 2014). As mentioned by Bhatnagar (2007) the most common retention drivers are "exciting work/challenge, career growth/learning, relationships/working with great people, fair pay and supportive management/great boss" (p. 17).

Bhattacharyya (2015) emphasizes on compensation and benefit strategy as a main tool to achieve employee retention. Compensation strategy may be differ from having a scale of payment or performance linked payment, both of them are successful talent retention strategies, but organizations must assure they are clear and fair for all employees. Bryant and Allen (2013) argued that although compensation and benefits is a driver of employee retention, but it is not as important as other factors. Starting with the most important factor which is exploring your employees and routinely gather information about their attitudes within organization to figure how satisfied and attached they are, know if your employees are in the process of leaving, if yes, organizations have to try to verse their intention. To retain employees, an organization needs to ensure a working environment where there is a supportive relationship between leaders and subordinates, the coordination relationship between coworkers, career development plan, minimum role 
conflict and clear roles. Accordingly to Slavković and associates (2015) and for the purpose of this study talent retention is studied through the following items; the organization has development programs for employees with high potential for performing operations, organization has career development programs for talented individuals and the organization has developed programs for retaining high-potential employees.

\section{Work/life Balance}

Organizations' path to maximize their profit was mainly concentrated on reserving their natural resources and finds ways to process their operations efficiently, but this is not the case anymore since human sustainability is another critical condition to increase profitability (Au and Ahmed, 2014). Generation Y who was born between 1977 and 1992 is increasingly entering the market and replacing their baby boomers in the workforce, generation $Y$ is more concerned and reserved about their non-work life responsibilities and family time more than their previous colleagues (Mazur-Wierzbicka, 2015). Millennial generation ( $Y$ Generation) will not hesitate to leave to another company that provides more attractive working conditions to balance their work and private life (Mazur-Wierzbicka, 2015).

Work/Life balance becomes an important concept for organizations to take it into consideration. Work/Life balance concept was emerged in 1970s as a women's issue and then evolves with time to become wider issues that involve many areas such as policy development and recruitment/retention policy, until recently arrive to focus on organization benefits (Moore, 2007), emergency leaves, sick leaves, annual leaves and working hours(Akanji, et al., 2015). Work life balance researches are still not covering the full picture of work life balance issues (Akanji, et al., 2015). It gets the least attention within the work-life research (Greenhaus and Allen, 2011). Akanji and associates (2015) criticized that work/life balance researches as they highlight work definition in one straight direction as "working hours within the organization" and miss the addition working consequences that can interfere with employees' personal life, such as time to arrive and come back from work, duties that employees get to be done from home and others. Valcour (2007) noted that it is "a concept whose popular usage has outplaced its theoretical development" (p. 1513).

The most cited definition of Work/Life balance it is about giving employees the opportunity to focus on both their personal and work life, avoid that work overbear their personal and social commitment (Moore, 2007). It is about giving employees a degree of independence to control their work and minimum clashes between employees' roles in work and life (Duxbury and Higgins, 2001; Mahanta, 2015). An organization that takes into consideration their employees' social responsibilities and gives them flexibility to perform their roles in their society seems to be highly attractive (Mazur-Wierzbicka, 2015). It gives employees the opportunity to balance and have control over their personal life, work life and respect their humanity, this helps organizations to prevent and overcome the negative consequences that can arise when neglecting employees' private life importance. Not only employees them self and their families are the only parts who benefits from work/life balance practices also communities will benefit too (Mariappanadar, 2013). 


\section{Reviewing the mediating role of work/life balance..}

Employees' moral decline, lose their faith in the organization and low motivation, commitment, innovation and productivity all can arise when an organization fails to balance its employees work and personal life (Gołaszewska-Kaczan, 2015), or in the worst scenario employees whoare valuable and rare resource will quit the work (Au and Ahmed, 2014). Human resources department policies and procedures must be dedicated to work with the benefits of all the organization, employees and community (Mariappanadar, 2013). Work life balance program will affect human resource management efforts in recruiting and retaining employees. Researchers try to figure out what issues can make work life balance differ from one context to another through examining cultural differences and different career stages (Haar, et al., 2014). Within the different cultural context; collectivism, or individualism, high or low gender egalitarianism, work/life balance will be an instrument for different organizations to achieve employees' job satisfaction, life satisfaction, lower mental pressure, lower physical pressure and lower depression levels, but work life balance effects will be more obvious in individualism and high gender egalitarianism societies (Haar, et al., 2014). Although Benito-Osorio and associates (2014) mentioned that work life balance policies and programs are significant issues for employees at all career stages, but organizations still have to avoid the adopting of one context approach of work life balance and apply to all employees, it has to adopt different approaches suited to different employees grouped with different interests (Yuile, et al., 2012).

For the purpose of this study Work/Life balance concept will be illustrated through items; Working hours, family care, fringe benefit and organization culture reinforcement (Gołaszewska-Kaczan, 2015). Those features represent different perks that the organization provides to its employees as a part of its work/life balance program such as part time working, leaves permission to take care of family issues, employees training to develop their abilities in handling their family issues, health insurance benefits, retirement plan and organization culture that support work/life balance orientation (Idrovo, et al., 2012).

\section{Motivational Drivers of Employee Engagement}

Kahn (1990) is one of the earliest writers to consider engagement; he regarded it as an employee experience showed in their relationship to their work. A positive and fulfilling state of mind characterized in an individual's dedication, focused energy and persistence directed towards organizational goals (Macey, et al., 2009; Mirah and Masa'deh, 2014; Alenezi et al., 2017; Tarhini et al., 2017 a, b; Masa'deh et al., 2018a, b ; Masa'deh et al., 2019). Karsan and Kruse (2011) define employee engagement as an employee motivation and their extent they are ready to contribute to organization success and their unrestrained efforts to accomplish their tasks in order to achieve organizational goals. They claim that an engaged employee is ready to go the extra miles for their organization, working for additional time, giving extra attention to his environment at the workplace, and showing a recognizable effort over his colleagues.

Following on, Armstrong (2012) identified employee engagement as employee commitment to their work and to the organization and how motivated they are to achieve high levels of performance. He stated that job engagement is accomplished 
when employees exercise discretionary effort to carry on their tasks because those tasks are interesting, challenging and rewarding. On a further level, organizational engagement takes place when employees harmonious with the values and purposes of their organization and believe that it is a great place to work in and to continue to work for. The importance of employee engagement as reported by Watkin (2002) is demonstrated in their role and what makes them behave in ways that link their achievements to both the objectives of the organization and themselves. He found that there is a considerable added value to their outstanding performance.

In today's competitive world of information, Tapscott and Caston (1993) mentioned that organizations are evolving at a rapid pace due to the continuous growth in technology and business activities. They are surrounded with opportunities where the real challenge is to dedicate huge efforts in attracting and retaining talented employees and assuring the delivery of their best performance to their current organization. The main drivers of employee engagement to reach a quality performance as indicated by (Bhuvanaiah and Raya, 2015) are; decision making authority, opportunities for growth and development, fair treatment, and leadership. These four main drivers will be studied and further explained in this section to understand their importance to talent management and how they affect organizations' performance.

\section{Decision Making Authority}

Perrin (2003) point out that when an employee is given the opportunity to make decisions about his/her own work, it leads to the employees acceptance to the given challenges and seeking the best possible way to accomplish the job. It gives the employee a sense of involvement in the decision making process which leads in appreciating the work and not feeling themselves as outsiders. Boxall and Purcell (2003) put that in the term of "employee voice". This term is increasingly used to explain the process and the organization structure that enables employees to contribute in the decision-making and influence the actions of the employer. When employers involve their employees in the decision-making process, it translates to their employees as a desire to educate them more about the aspects of the organization and engage them in the management's actions (Marchington, et al., 1992). It is also seen as a stability action to the employees that channel their anxieties and misgivings to the company's own benefits and better performance.

Decision making authority will boost organizations' efficiency and effectiveness since an internal circle of knowledge will be shared between employees and managers and open a channel of communication from top to bottom and via versa. Bhuvanaiah and Raya (2015) describes that decision making authority will rise employees' satisfaction and commitment. Decision making authority is not just allowing employees to schedule their working hours and give their opinions in facilities, it goes beyond that let them participate in solving any conflict that arise in their department (Bhuvanaiah and Raya, 2015).

\section{Opportunities for Growth and Development}

As described by Perrin (2003), it is essential for employees to have the opportunities to learn and develop in their workplace. Understanding employees' skills, aspirations and 


\section{Reviewing the mediating role of work/life balance..}

abilities, help management to develop a right learning culture that strategically improves one's confidence at work and leads to performance excellence. A learning culture as described by Reynolds (2004) is a "growth medium" where employees are encouraged and empowered to develop self-managed characteristics that motivates them to develop the organizations' practices and commit more. Learning and development to employees and how it can be directly linked to the organizational performance. He mentions how a motivated employee is most likely to develop his/her performance if he/she is offered the chance and the opportunity to learn extra skills of the day to day duties. Oltra and Vivas-Lo'pez (2013) express that there is a relation between talent management and learning management. Furthermore, they address that talent management can be an effective tool to create a learning organization. Talent management is about building a talent pool of qualified and knowledgeable employees.

\section{Fair Treatment}

Fairness is one tactic of employee engagement; it is a strategy to welfare the wellbeing of employees within the organization andenhances their feeling of importance as a crucial element (Guest, 2014). In a healthy and supportive work environment where employees are treated on fair basis, given the opportunity to communicate and are empowered to take decisions, they are expected to outperform the given task (Perrin, 2003). Empowering employees can be achieved by assigning the right tasks and activities to the right person to give the employees a fair chance in exceeding their goals. Empowerment, fuels an employee with a sense of personal worth and power to make a difference. Empowerment is about making employees' job easier and smoother to carry on and to give them the power to face the accumulated challenges in their work.

\section{Leadership}

Leadership is the process of guiding and influencing others and the ability to inspire others to achieve goals at the same time feel that they are empowered and accomplished; it is how to control and motivate employees to work hard to achieve the group goals. Leaders are people who have the vision to lead and guide others through the journey; they are willing to appreciate and recognize good work, support employees in their development and invention. It is found by Perrin (2003) that building the right leadership can have motivational and inspirational drivers that affect employee engagement. A leadership management illustrates a higher impact on employees and their engagement. "Leaders have large shadows, and employees are watching everything they do" (Kelleher, 2015, p: 1).

\section{Organization Performance}

Business environment is no longer an easy place to conduct business and work smoothly without obstacles, as mentioned earlier business environment becomes uncertain and complex due to many reasons that range from globalization, technological advancement and needy customers, that put organizationsunder pressure to keep chasing its performance and grow into high performance organization that outperform others in financial and non-financial results (Waal, et al., 2014) and working towards being an ideal organization. Organizations that keep track of their performance are better than others in being prepared for uncertainty, ambiguity and risks. Evaluating an organizations' performance vary in its techniques and measurements according to the purpose of 
evaluation; at the first stage in the 1940 organizational performance was assessed financially, measuring is the organization profit (Martz, 2013) but this focus was criticized because of its backward viewpoint and lack of focus on organizational strategies.

How to measure organization performance has evolved over time to give more practical evidence and better techniques to deal with environment complexity; in 1957 it was linked to organizational flexibility and evolvement with time through including and achieving goals and objectives, adaptive ability, social responsibilities and others (Martz, 2013). Jiang, et al. (2012) divide organization performance outcomes into three types of outcome; human resources outcomes that emphasize employee outcomes such as commitment, satisfaction and motivation, operational outcomes that concerned with organization productivity and financial outcomes that represent organizations' economic status. For the purpose of this study, we will concentrate on Human resource outcomes as a part of organization performance explained by its two main dimensions of human capital and employee motivation (Jiang, et al., 2012).

\section{Human Capital}

Human capital is the knowledge, skills and abilities of employees and how these employees' capabilities are managed efficiently to influence organizations' competitive advantage and help achieving organizational strategy (Baron, 2011) since human capital is hard to be imitated (Jiang, et al., 2012). It is about seeing people as assets more than cost because of their ability to gain a sustainable competitive advantage (Pickett, 2005). Human Capital is about how organizations can use employee engagement and talent development process as a tool to encourage employees to share and use their human capital in the benefit of their organization and achieve its goals (Baron, 2011). The greater human capital committed, the more financially profitable the organization is (Jiang, et al., 2012; Pickett, 2005). Baron (2011) mentioned main factors that can affect human capital management efficiency; emphasizing on learning, sharing knowledge and ideas within all levels of organization, managers and supervisors encourage efficiencies and effectiveness and employee commitment. Human capital can be optimized in organizations through Human resources processes and practices, implementing the right recruitment and selection process and practical training (Nieves and Quintana, 2016).

\section{Motivation}

Motivation is a very important factor in driving organizational success. It is about stimulating people and encouraging them to perform their work efficiently and effectively. Motivation can define as a conditional effort from employees to accomplish organization goals and objectives with also having the belief of some individual gain and achieving some personal needs (Johnson, 2004). Motivation is the responsibility of managers and supervisors through being a role model of how things are done correctly, give employee appreciation and recognition and advice how things can be done professionally (Vratskikh, et al., 2016).

\section{Talent Management and Organization Performance}

Bat and Yalcin (2015) conducted a research about Vodafone by implementing a case study model to answer the question "what are the contributions of talent management to the organization in Vodafone?", they illustrated that talent management is becoming 


\section{Reviewing the mediating role of work/life balance..}

a worldwide concept that organizations focus on, specifically in the United States and Europe. They stated the importance of developing a talent management plan that is convenient with organizations' strategic goals, and how talent management is a continuous process stream, start with acquiring talented employees who fit within the organizations' structure and culture and continuous development through the right skills to finally secure their retention to the organization. They conclude what positive outcomes the organizations have when designing and implementing the right talent management program which improves organizations' performance from many sides; cost advantages, motivated employees, the ability to fill higher level management vacancies from organizations' internal talent pool and many other positive outcomes.

Moreover, a research proceeded by Muntean (2014) conducted through a survey and questionnaire along 94 multinational organizations in Sibui to study the relationship between talent management and organization performance. In this research they indicate human capital importance to organizational success and what value they added. Talent management should be a human resources management priority to concentrate on because of the positive results it has on the organization, for not losing the best employees within the organization and to be able to compete in the global and competitive environment. They recommend having a systematic human resource practices and implications to keep right track and development of talent employees within the organization and found that those practices boost organizations' performance.

\section{Talent Management and Work Life Balance}

Talent management is about attracting, developing and retaining qualified employees to satisfy organizational needs (Ulrich and Allen, 2014; Mathew, 2015). This process is not an easy task anymore and its becoming harder with time, where organizations face more work force challenges, where rate of birth is declining, older people are compromising high percentage of the population, women percentage comprise nearly half of the workforce and a family with one parent is more common (Kossek, et al., 2015). Kossek and associates (2015) suggested that organizations should be more flexible to get over work force challenges. They studied the advantages of work life balance on talent management and suggested how to avoid the negative consequences that may arise with work life balance practices. They conclude in their research "Balanced Workplace Flexibility: AVOIDING THE TRAPS" that work life balance practices and work flexibility support and leverage organizations' efforts in tracking, developing and retaining talent employees.

The main reason why companies are looking after work life balance is to be a main part of their human resources management practice. It is to retain their best people and not lose them.Financial consequence is the major disadvantage that organization will face next to many others when losing their best people (Parakandi and Behery, 2016). Parakandi and Behery (2016) studied work life balance practices within national organization in the United Arab Emirates, they applied qualitative and exploratory studies which complemented by case study on a sample consist of 14 companies from different industries, primary data were collected through semi-structured interviews. Although United Arab Emirates labor force was mainly composed of other nationalities other than UAE citizens who find UAE an attractive, high income developing economy 
and their intention to work is a priority, but still (Parakandi and Behery, 2016) find that UAE companies had recognized the importance of work life balance to gain long-term healthy and sustainable business which give them the opportunity to manage their talent correctly and retain the best ones.

\section{Talent Management and Motivational Drivers of Employee Engagement}

Jauhari and associates (2013) in their study "Talent Management and Employee Engagement: Insights from INFOTECH Enterprises Ltd" Pointed out the importance of talent management and employee engagement to organization to face their dynamic and unpredictable environment. They applied their study in the IT industry in India with reference to Infotech Company. They discussed the talent management issue as the process of acquiring, developing and retaining talented employees and the importance of those talents for organizational growth and success. They find that one of the successful ways to manage talents and devote their efforts to the best of the organization is through concentrating on employee engagement. They also discuss many issues organizations can apply to increase their employee engagement, where financial and non-financial rewards both matters. Leadership style, fairness, compensation, challenging tasks, fair salary, recognition and many other issues can play critical role in enhancing employee engagement.

Another researcher who emphasis on the advantages of having engaged talent employees in the organization is (Ross, 2013). She built her research through a combination of literature, early doctoral research and practitioner experience in talent management and leadership development. The paper discussed that talent management is not an easy task; it has obstacles that leaders must take into consideration. Ross (2013) suggests focusing on employee engagement and talent development to overcome the flaws that come when recruiting the right people, but let them lose their path of development within the organization ambiguous.

\section{Work Life Balance and Organization Performance}

As Benito-Osorio and associates (2014) applied a research on a sample composed of firms that are listed in the Spanish Stock Index (IBEX-35) to analyze the relationship between Work/Life balance practices that organizations adapt and organizations' performance outcomes. They discuss the fact that nowadays employees are looking to balance between their personal lives and working life, a generation who wants to minimize the interfering of work in their family time and responsibilities. Although they recognized that the lack of work/life balance practices will not be a threat to organization performance, but they approved that having those practices will lift so many advantages for organizations such as having employees with higher commitment, motivation, satisfaction and productivity. After analyzing the data about the companies which were gathered through their annual reports, websites and corporate social responsibilities report they find that, implementing an appropriate work/life balance practices will improve organizations' performance.

Moreover, from five decades ago work life balance is raised as an important topic because employees are more concern to equalize between their business life and family life, but still an effective work life balance programs are applied within a small number of 


\section{Reviewing the mediating role of work/life balance..}

big organizations and specific countries (Jha and Malviya, 2015). Jha and Malviya (2015) studied the presence of work life balance programs in nowadays competitive environment by observing a number of Indian companies and supported their research by the study of Chandra, 2012 on some Indian companies too. They found that the presence of work life balance programs will enhance the effectiveness of an organization's performance.

\section{Conclusion}

As J.W. Marriot, founder of Marriot Hotels once said, "if you take care of your people, they will take care of your customers and our business will take care of itself". As Bedarkar and Pandita (2014) stated that, for the organization to be successful, it has to give a priority for employee engagement. Organizations should be surrounded within a culture that support employee engagement because engaged employees will be a powerful organization tool and can used to compete and survive within its competitive and global environment. Through their research which was based on a systematic review of literature on employee engagement, they found many drivers that will increase employee engagement within an organization, make employees' working experience enjoyable and enhance employees' working efforts and performance, which will be reflected positively on organizational performance.

Breevaart and associates (2015) in their research Leader-member exchange, work engagement, and job performance studied the mediating role of employee engagement to link between leaders and member relationships and organizational performance. They start the flow of their framework with leader-member relationship at the beginning, where the existence of positive relationship will provide a positive outcome. Firstly, leaders with good relationship with their employees will give the right roles to them and trust their ability to perform their job correctly, they will let their employees experience independence and empowerment. Secondly, leaders who have a positive relationship with their subordinates will allow them to communicate what assignments they enjoy working on and get it done efficiently and effectively, so give them the opportunity to develop. Thirdly, a leader with a good relationship with his employees will create a working environment where colleagues have a positive relationship too. Finally, Breevaart and associates (2015) found that those mentioned positive outcomes of good leaders-member relationship; autonomy, empowerment, development opportunities and cooperation between colleagues will lead to employee engagement, where employees will be more productive, motivated and satisfied which will drive organizations to perform better. Also, organizations can improve their talent management practicesto attract, develop and retain talented employees through minimizing theconflict between those employees work responsibilities and life responsibilities (Obeidat, et al., 2017). Many big companies in the USA such as Dell and Deloitte are emphasizing on the benefits of work life balance practices on managing talented employees and achieving organization's success. As mentioned earlier by Jauhari and associates (2013) employee engagement is a tool to connect talented employees to their organization and devote their efforts to achieve organization's success and growth. 


\section{References}

Akanji, B., Mordi, C., \& Ojo, S. (2015). Reviewing Gaps in Work-Life Research and Prospecting Conceptual Advancement. Petroleum-Gas University of Ploiesti Bulletin, Technical Series, 67(3).

Alenezi, H., Tarhini, A., Alalwan, A., \& Al-Qirim, N. (2017). Factors Affecting the Adoption of E-Government in Kuwait: A Qualitative Study. Electronic Journal of e-Government, 15(2), 84-102.

Armstrong, M. (2012). Armstrong's Handbook of Human Resource Management Practice. 12th ed. London: Kogan Page.

Au, W. C., \& Ahmed, P. K. (2014). Sustainable People Management through Work-Life Balance: A Study of the Malaysian Chinese Context. Asia-Pacific Journal of Business Administration, 6(3), 262-280.

Axelrod, W. (2015). How Exceptional Managers Use Everyday Psychology to Develop their People. Industrial and Commercial Training, 47(3), 121-126.

Bandari, N. K., \& Migiro, S. (2015). Talent Management in Indian IT \& ITES Sectors. Indian Journal of Industrial Relations, 51(1), 43-57.

Baron, A. (2011). Measuring Human Capital. Strategic HR Review, 10(2), 30-35.

Bat, M., \& Yalcin, M. (2015). An Evaluation of Talent Management from an Organizational Perspective: The Case of Vodafone. Global Media Journal: Turkish Edition, 6(11).

Bedarkar, M., \& Pandita, D. (2014). A Study on the Drivers of Employee Engagement Impacting Employee Performance. Procedia-Social and Behavioral Sciences, 133, 106115.

Benito-Osorio, D., Muñoz-Aguado, L., \& Villar, C. (2014). The Impact of Family and WorkLife Balance Policies on the Performance of Spanish Listed Companies.M@n@ gement, 17(4), 214-236.

Bhatnagar, J. (2007). Talent Management Strategy of Employee Engagement in Indian ITES Employees: Key to Retention. Employee Relations, 29(6), 640-663.

Bhattacharyya, D. K. (2015). Compensation and Benefits Program a Mediating Variable for Talent Retention: A Study of Two Century-Old Indian Organizations. Compensation \& Benefits Review, 47(2), 75-80.

Bhuvanaiah, T., \& Raya, R. P. (2015). Mechanism of Improved Performance: Intrinsic Motivation and Employee Engagement. SCMS Journal of Indian Management, 12(4), 92.

Boxall, P.F., \& Purcell, J (2003). Strategy and Human Resource Management. Palgrave Macmillan, Basingstoke. 


\section{Reviewing the mediating role of work/life balance..}

Breevaart, K., Bakker, A. B., Demerouti, E., \& van den Heuvel, M. (2015). Leader-Member Exchange, Work Engagement, and Job Performance. Journal of Managerial Psychology, 30(7), 754-770.

Bryant, P. C., \& Allen, D. G. (2013). Compensation, Benefits and Employee Turnover: HR Strategies for Retaining Top Talent. Compensation \& Benefits Review, 45(3), 171-175.

Cascio, W. F., \& Boudreau, J. W. (2016). The Search for Global Competence: From International HR to Talent Management. Journal of World Business, 51(1), 103-114.

Coff, R., \& Kryscynski, D. (2011). Invited Editorial: Drilling for Micro-Foundations of Human Capital-based Competitive Advantages. Journal of Management, 37(5), 14291443.

Duxbury, L. E., \& Higgins, C. A. (2001). Work-Life Balance in the New Millennium: Where are We? Where do We Need to Go? (Vol. 4). Ottawa: Canadian Policy Research Network.

Egerová, D. (2013). Integrated Talent Management-A Challenge or Necessity for Present Management. Problems of Management in the 21st Century, 6, 4-6.

Epie, C. (2014). Improving Talent Retention in an SME in the Nigerian Environment: Reflections on a Case Study. International Journal of Employment Studies, 22(1), 60.

Garavan, T. N., Carbery, R., \& Rock, A. (2012). Mapping Talent Development: Definition, Scope and Architecture. European Journal of Training and Development, 36(1), 5-24.

George, C. (2015). Retaining Professional Workers: What Makes them Stay?. Employee Relations, 37(1), 102-121.

Glen, C. (2006). Key Skills Retention and Motivation: The War for Talent Still Rages and Retention is the High Ground. Industrial and Commercial Training, 38(1), 37-45.

Gołaszewska-Kaczan, U. (2015). Actions for Promoting Work-Life Balance as an Element of Corporate Social Responsibility. Prace Naukowe Uniwersytetu Ekonomicznego we Wrocławiu, 387, 54-65.

Greenhaus, J., \& Allen, T.D. (2011). Hand Book of Occupational Health Psychology, (2nd ed.). Washington, DC: American Psychology Association.

Guest, D. (2014). Employee Engagement: A Sceptical Analysis. Journal of Organizational Effectiveness: People and Performance, 1(2), 141-156.

Haar, J. M., Russo, M., Suñe, A., \& Ollier-Malaterre, A. (2014). Outcomes of Work-Life Balance on Job Satisfaction, Life Satisfaction and Mental Health: A Study Across Seven Cultures. Journal of Vocational Behavior, 85(3), 361-373. 
Harvey, W.S. (2014). Winning the Global Talent War: A Policy Perspective. Journal of Chinese Human Resource Management, 5(1), 62-74.

Hejase, H. J., Hejase, A. J., Mikdashi, G., \& Bazeih, Z. F. (2016). Talent Management Challenges: An Exploratory Assessment from Lebanon. International Journal of Business Management and Economic Research, 7, 504-520.

Idrovo Carlier, S., Leon Llorente, C., \& Grau Grau, M. (2012). Comparing Work-Life Balance in Spanish and Latin-American Countries. European Journal of Training and Development, 36(2/3), 286-307.

Jauhari, V., Sehgal, R., \& Sehgal, P. (2013). Talent Management and Employee Engagement: Insights from Infotech Enterprises LTD. Journal of Services Research, 13(1), 161.

Jha, S., \& Malviya, V. (2015). Leveraging Work Life Balance for Organizational Effectiveness. Apeejay Business Review, 14(2).

Jiang, K., Lepak, D. P., Hu, J., \& Baer, J. C. (2012). How does Human Resource Management Influence Organizational Outcomes? A Meta-Analytic Investigation of Mediating Mechanisms. Academy of Management Journal, 55(6), 1264-1294.

Kahn, W.A. (1990). Psychological Conditions of Personal Engagement and Disengagement at Work. Academy of Management Journal, 33, 692-724.

Karsan, R., \& Kruse, K. (2011). We: How to Increase Performance and Profits Through Full Engagement. John Wiley \& Sons.

Kelleher, B. (2015). 10 Practical Employee Engagement Practices. Business NH Magazine, 32(5), 11-12.

Kim, S., \& McLean, G. N. (2012). Global Talent Management: Necessity, Challenges, and the Roles of HRD. Advances in Developing Human Resources, 14(4), 566-585.

Kossek, E. E., Thompson, R. J., \& Lautsch, B. A. (2015). Balanced Workplace Flexibility. California Management Review, 57(4), 5-25.

Kucherov, D., \& Zavyalova, E. (2012). HRD Practices and Talent Management in the Companies with the Employer Brand. European Journal of Training and Development, 36(1), 86-104.

Latukha, M., \& Tsukanova, T. (2015). Talented Employees in Russian and Foreign Companies. Voprosy Economiki, 1.

Macey, W.H., Schneider, B., Barbera, K., \& Young, S. (2009). Employee Engagement, Malden, MA: Wiley-Blackwell. 


\section{Reviewing the mediating role of work/life balance..}

Mahanta, M. (2015). Exploring the Relationship between Emotional Intelligence and Work-Life Balance in the Service Industry. IUP Journal of Organizational Behavior, 14(2).

Majeed, A. (2013). Application of Business Process through Talent Management: An Empirical Study. Journal of Marketing and Management, 4(2), 46.

Marchington, M., Goodman, J., Wilkinson, A., \& Ackers, P. (1992). New Developments in Employee Involvement, London: HMSO.

Mariappanadar, S. (2013). A Conceptual Framework for Cost Measures of Harm of HRM Practices. Asia-Pacific Journal of Business Administration, 5(2), 103-114.

Martz, W. (2013). Evaluating Organizational Performance: Rational, Natural, and Open System Models. American Journal of Evaluation, 34(3), 385-401.

Masa'deh, R., Alananzeh, O., Algudah, O., \& Tarhini, A. (2018a). The Effect of Promotional Mix on Hotel Performance during the Political Crisis in the Middle East. Journal of Hospitality and Tourism Technology, 9(1), 33-49.

Masa'deh, R., Al-Henzab, J., Tarhini, A., \& Obeidat, B. (2018b). The Associations among Market Orientation, Technology Orientation, Entrepreneurial Orientation and Organizational Performance. Benchmarking: An International Journal, 25(8), 3117-3142.

Masa'deh, R., Almajali, D., Alrowwad, A., \& Obeidat, B. (2019). The Role of Knowledge Management Infrastructure in Enhancing Job Satisfaction: A Developing Country Perspective. Interdisciplinary Journal of Information, Knowledge, and Management, 14, $1-25$.

Mathew, A. (2015). Talent Management Practices in Select Organizations in India. Global Business Review, 16(1), 137-150.

Mazur-Wierzbicka, E. (2015). Implementing the Work-Life Balance as a CSR Tool in Polish Companies. Realizacja Work-Life Balance Jako Jednego Z Narzedzi Csr W Polskich Przedsiebiorstwach, 387, 109-121.

Mehdiabadi, A., \& Li, J. (2016). Understanding Talent Development and Implications for Human Resource Development: An Integrative Literature Review. Human Resource Development Review, 15(3), 263-294.

Mirah, D., \& Masa'deh, R. (2014). An Analysis of the Insurance Industry Regulator in Saudi Arabia and Jordan through the Comparison with Insurance Industry Regulator in the UK. Asian Social Science, 10(3), 211-220.

Moore, F. (2007). Work-Life Balance: Contrasting Managers and Workers in an MNC. Employee relations, 29(4), 385-399. 
Muntean, S. (2014). Talent Management and its Contributions to the Performance of the Multinational Organizations. Management and Economics, 3(75), 300-306.

Nieves, J. \& Quintana, A. (2016). Human Resources Practices and Innovation in the Hotel Industry: The Mediating Role of Human Capital. Tourism and Hospitality Research, 1-12.

Nijs, S., Gallardo-Gallardo, E., Dries, N., \& Sels, L. (2014). A Multidisciplinary Review into the Definition, Operationalization, and Measurement of Talent. Journal of World Business, 49(2), 180-191.

Nilsson, S., \& Ellström, P. E. (2012). Employability and Talent Management: Challenges for HRD Practices. European Journal of Training and Development, 36(1), 26-45.

Obeidat, B., Tarhini, A., Masa'deh, R., \& Aqqad, N. (2017). The Impact of Intellectual Capital on Innovation via the Mediating Role of Knowledge Management: A Structural Equation Modeling Approach. International Journal of Knowledge Management Studies, 8(3/4), 273-298.

Oltra, V., \& Vivas-López, S. (2013). Boosting Organizational Learning through Team-based Talent Management: What is the Evidence from Large Spanish Firms?. The International Journal of Human Resource Management, 24(9), 1853-1871.

Panda, S., \& Sahoo, C. K. (2015). Strategic Talent Development Interventions: An Analysis. Industrial and Commercial Training, 47(1), 15-22.

Parakandi, M., \& Behery, M. (2016). Sustainable Human Resources: Examining the Status of Organizational Work-Life Balance Practices in the United Arab Emirates. Renewable and Sustainable Energy Reviews, 55, 1370-1379.

Perrin, T. (2003). Working Today: Understanding What Drives Employee Engagement. Tower Perrin. Retrieved from:http://www.keepem.com/doc_files/ Towers_Perrin_Talent_2003(TheFinal).pdf

Pickett, L. (2005). Optimising Human Capital: Measuring What Really Matters. Industrial and Commercial Training, 37(6), 299-303.

Reynolds, J. (2004). Helping People Learn, London: CIPD.

Ross, S. (2013). Talent Derailment: A Multi-Dimensional Perspective for Understanding Talent. Industrial and Commercial Training, 45(1), 12-17.

Samantara, R. \& Sharma, N. (2014). Talent Management at Tesco HSC-A Case Study. Management and Labour Studies, 39(4), 477-485.

Slavković, M., Babić, V., \& Stojanović-Aleksić, V. (2015). Talent Management: Opportunities and Limitations for Serbian Organizations. Teme: Casopis za Društvene Nauke, 39(2). 
Tansley, C. (2011). What do we Mean by the Term "Talent" in Talent Management?. Industrial and Commercial Training, 43(5), 266-274.

Tapscott, D., \& Caston, A. (1993). Paradigm Shift: The New Promise of Information Technology. New York: McGraw Hill, Inc.

Tarhini, A., Al-Badi, A., Almajali, M., \& Alrabayaah, S. (2017a). Factors Influencing Employees' Intention to Use Cloud Computing. Journal of Management and Strategy, $8(2), 47$.

Tarhini, A., Al-Busaidi, K., Bany Mohammed, A., \& Maqableh, M. (2017b). Factors Influencing Students' Adoption of E-Learning: A Structural Equation Modeling Approach. Journal of International Education in Business, 10(2), 164-182.

Thunnissen, M. (2016). Talent Management: For What, How and How Well? An Empirical Exploration of Talent Management in Practice. Employee Relations, 38(1), 57-72.

Toterhi, T., \& Recardo, R. J. (2013). The Talent Funnel: How to Surface Key Human Resources. Global Business and Organizational Excellence, 32(5), 22-44.

Ulrich, D. \& Allen, J. (2014). Talent Accelerator: Understanding How Talent Delivers Performance for Asian Firms. South Asian Journal of Human Resources Management, 1(1), 1-23.

Valcour, M. (2007). Work-based Resources as Moderators of the Relationship between Work Hours and Satisfaction with Work-Family Balance. Journal of Applied Psychology, 92(6), 1512.

Vidal-Salazar, M. D., Cordón-Pozo, E., \& de la Torre-Ruiz, J. M. (2016). Flexibility of Benefit Systems and Firms' Attraction and Retention Capacities. Employee Relations, 38(4), 487-504.

Vinnie, J., Rajesh, S. \& Pooja, S. (2013). Talent Management and Employee Engagement: Insights from Infotech Enterprise LTD. Journal of Services Research, 13(1), 161-186.

Vratskikh, I., Masa'deh, R., Al-Lozi, M., \& Maqableh, M. (2016). The Impact of Emotional Intelligence on Job Performance via the Mediating Role of Job Satisfaction. International Journal of Business and Management, 11(2), 69-91.

Watkin, C. (2002). Engage Employees to Boost Performance. Selection \& Development Review, 18(2), 3-6.

Yuile, C., Chang, A., Gudmundsson, A., \& Sawang, S. (2012). The Role of Life Friendly Policies on Employees' Work-Life Balance. Journal of Management \& Organization, 18(01), 53-63. 